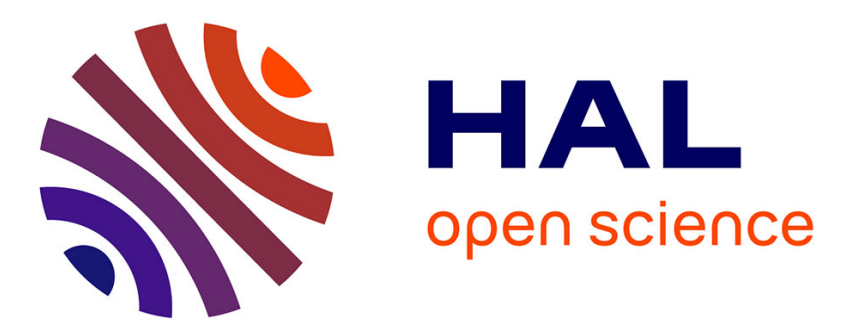

\title{
Down-regulation of actin genes precedes microfilament network disruption and actin cleavage during p53 mediated-apoptosis
}

\author{
Isabelle Guenal, Yanick Risler, Bernard Mignotte
}

\section{To cite this version:}

Isabelle Guenal, Yanick Risler, Bernard Mignotte. Down-regulation of actin genes precedes microfilament network disruption and actin cleavage during p53 mediated-apoptosis. Journal of Cell Science, 1997. hal-03036445

\author{
HAL Id: hal-03036445 \\ https://hal.science/hal-03036445
}

Submitted on 2 Dec 2020

HAL is a multi-disciplinary open access archive for the deposit and dissemination of scientific research documents, whether they are published or not. The documents may come from teaching and research institutions in France or abroad, or from public or private research centers.
L'archive ouverte pluridisciplinaire HAL, est destinée au dépôt et à la diffusion de documents scientifiques de niveau recherche, publiés ou non, émanant des établissements d'enseignement et de recherche français ou étrangers, des laboratoires publics ou privés. 


\title{
Down-regulation of actin genes precedes microfilament network disruption
}

\section{and actin cleavage during p53-mediated apoptosis}

\author{
Isabelle Guénal ${ }^{1}$, Yanick Risler ${ }^{1}$ and Bernard Mignotte ${ }^{1,2}$ \\ ${ }^{1}$ Centre de Génétique Moléculaire, UPR 9061 du CNRS, F-91198 Gif-sur-Yvette cedex, France \\ 2Université de Versailles-St Quentin, 45 Avenue des Etats-Unis, F-78035 Versailles cedex, France \\ *Author for correspondence (e-mail: mignotte@cgm.cnrs-gif.fr)
}

\section{SUMMARY}

Inactivation of Simian Virus 40 large $\mathbf{T}$ antigen, in cells immortalized with conditional mutants, leads to activation of p53 and apoptosis. We used the mRNA differential display method to identify genes differentially expressed during this process. We found that steady-state levels of mRNA for cytoplasmic actins decreased early during apoptosis. We also showed that, although the steady-state level of the corresponding proteins is not profoundly affected, they are substrates for an interleukin 1- $\beta$ converting enzyme (ICE)-like protease activated during the process. However, only a very small fraction of actin is pro- teolysed during the early stages of apoptosis. The microfilament network is affected and non polymerized actin accumulates in apoptotic bodies after the decrease of mRNA levels, but before a significant amount of actin is cleaved. This suggests that down-regulation of actin genes may be involved in microfilament rearrangements during p53mediated apoptosis.

Key words: Apoptosis, p53, Simian Virus 40, Microfilament, Actin gene, ICE-like protease

\section{INTRODUCTION}

Programmed cell death (PCD) is an active process of cellular self-destruction and in most cases serves a biologically meaningful homeostatic function (Kroemer et al., 1995; Thompson, 1995). Apoptosis, which has been defined from morphological considerations (Kerr et al., 1972), is the most often encountered form of PCD, though not the only form (Clarke, 1990; Schwartz et al., 1993). Apoptosis can be induced by a wide range of stimuli. During the subsequent effector phase, the numerous apoptosis inducing stimuli seem to converge onto a few stereotypical pathways and at a certain point, the cells become irreversibly committed to death. During the successive degradation phase, vital structures and functions are destroyed giving rise to the full-blown phenotype of apoptosis (Kroemer et al., 1995). At the nuclear level, apoptosis is typically accompanied by condensation and fragmentation of chromatin and nucleus. Cytoplasmic boiling, a marked convolution of the cellular surface and the development of pedunculated protuberances that separate to produce membrane-enclosed apoptotic bodies are also seen. In vivo, apoptotic bodies are phagocytosed and digested by adjacent cells or macrophages. The dramatic changes in cell shape suggest a role for the cytoskeleton in this process. Experiments performed with cytochalasins have suggested that actin polymerization is necessary for the formation of apoptotic bodies in the latter stages of HL60 cell apoptosis (Cotter et al., 1992). Other results suggest that blebbing of the cytoplasmic membrane during apoptosis is associated with a deficiency of filamentous actin (Endresen et al., 1995a,b). In the case of adherent cells, cytoplasmic condensation begins with loss of cell-cell or cellsubstrate contacts. In vitro, rounding up of previously flat substrate-attached cells is easily visible under the light microscope and is rapidly followed by an increase in density and a decrease in volume common to nearly all apoptotic cells that can be monitored by flow cytometry (Nicoletti et al., 1991; Swat et al., 1991; Shi et al., 1992; Vayssière et al., 1994).

Genetic studies of PCD in the nematode Caenorhabditis elegans provided evidence that PCD involves a cell-intrinsic death program (Ellis et al., 1991). Among the 14 identified genes participating in C. elegans developmental PCD, three were found to act during the effector phase: $c e d-9$ which is a suppressor of PCD and ced-3 and ced-4 which are required for PCD. Ced-9 is homologous to the mammalian bcl-2 gene family, ced-4 has no mammalian homologue identified so far and ced-3 is homologous to the interleukin- $1-\beta$-converting enzyme (ICE) gene family encoding cysteine proteases involved in mammalian apoptosis (Kumar, 1995). A role for such proteases in cytoskeleton rearrangements during apoptosis has been suggested (Martin and Green, 1995). Indeed, cleavage of Gas2 (growth arrest specific protein) by ICE-like proteases can lead to the formation of a Gas2 derivative able to trigger changes in actin cytoskeleton and cell morphology (Brancolini et al., 1995). A calpain-mediated proteolysis of the actin-associated protein fodrin has also been reported (Martin et al., 1995). More recently, actin itself has been shown to be a substrate for an ICE-like protease, different from ICE, activated during U937 leukemia cells apoptosis (Mashima et al., 1995) and for ICE itself in in vitro experiments (Kayalar et al., 1996). 
It has been previously observed that rodent embryo fibroblasts conditionally immortalized by temperature sensitive mutants of SV40 large T antigen undergo apoptosis at the restrictive temperature (Yanai and Obinata, 1994; Zheng et al., 1994). Apoptosis of these cells in restrictive conditions appears to be mediated by the release of wild-type p53 from the large $\mathrm{T}$ antigen as judged by coprecipitation experiments and its ability to induce $m d m-2$ (Zheng et al., 1994), wafl/cipl (Guénal and Mignotte, 1995) and bax (I. G., unpublished results) expression. We also observed that clusterin is induced late during the process and that some other genes identified during thymocyte and lymphocyte apoptosis are not induced, showing that the pattern of gene induction is in part specific to the system studied (Guénal and Mignotte, 1995).

In this report we have used the mRNA differential display method to identify novel genes whose expression is modulated during apoptosis. We find that actin genes are down-regulated during apoptosis before any cleavage of actin can be detected. This suggests that gene repression could also be involved in microfilament reorganization during apoptosis.

\section{MATERIALS AND METHODS}

\section{Cell lines and cell culture}

The REtsAF cell line was isolated at low cell density from a rat embryo fibroblast culture infected with a temperature sensitive mutant (tsA58) of SV40 (Petit et al., 1983). It is immortal at $33^{\circ} \mathrm{C}$ and undergoes apoptosis upon shift up to $39.5^{\circ} \mathrm{C}$ (Zheng et al., 1994). REtsAF-Rev1 was derived from REtsAF by selection for proliferation at $39.5^{\circ} \mathrm{C}$ (Mignotte et al., 1990) and is immortal at both 33 and $39.5^{\circ} \mathrm{C}$. Cells were propagated in Dulbecco's modified Eagle's medium (DMEM) supplemented with $10 \%$ fetal calf serum or DMEM/F12 supplemented with $2 \%$ Ultroser G, plus penicillin $(100 \mu \mathrm{g} / \mathrm{ml})$ and streptomycin $(100 \mathrm{i} . \mathrm{u} . / \mathrm{ml})$ under $5 \% \mathrm{CO}_{2}$. The cultures were screened regularly for the absence of mycoplasma.

\section{mRNA differential display}

Total cellular RNA was isolated from cells by the method of Chirgwin et al. (1979). The differential display was performed essentially as described by Liang and Pardee (1992). Briefly, total RNA from REtsAF, REtsAF-Rev1 and RELPB grown at $33^{\circ} \mathrm{C}$ or shifted up to $39.5^{\circ} \mathrm{C}$ for various times was reverse transcribed, amplified by PCR using $\mathrm{T}_{12} \mathrm{VC}$ as a $3^{\prime}$-primer and GGGTAACGCC as a $5^{\prime}$-primer and electrophoresed on a sequencing gel. The size of the fragments was estimated by comparison with the end-labeled MspI fragment of pBR322 and the band of interest was isolated from the gel as described by Liang et al. (1995), reamplified in the same PCR conditions and cloned using the pCR-Script ${ }^{\mathrm{TM}} \mathrm{SK}(+)$ cloning kit (Stratagene) according to the manufacturer's instructions.

\section{Northern blotting}

Gene expression was assayed by northern blotting analysis. Total RNA $(10 \mu \mathrm{g})$ was fractionated on a $1 \%$ agarose-formamide gel and transferred to nylon membrane (HybondN, Amersham) according to the procedure of Reed and Mann (1985). Probes for $\beta$-actin and $\gamma$ actin were obtained, respectively, by labeling of the insert of plasmid pSP64-HFßA-3'UT (Kocher and Gabbiani, 1986) and pCR- $\gamma$ A$3^{\prime} \mathrm{UT}$, respectively, with $\left[{ }^{32} \mathrm{P}\right] \mathrm{dCTP}$ by random primers using the Megaprime $^{\mathrm{TM}}$ labeling system (Amersham). The amount of RNA blotted for each sample was normalized by hybridization of $18 \mathrm{~S}$ rDNA probes to the northern blots. The probe for $18 \mathrm{~S}$ rRNA was labeled with $\left[{ }^{32} \mathrm{P}\right] \mathrm{dCTP}$ by PCR with $5^{\prime}$ ATGCGGCGGCGTTATTC3' and 5'GCGACGGGCGGTGTGTA3' as primers. PCR radiolabeling reactions $(100 \mu \mathrm{l})$ contained $10 \mathrm{ng}$ of an $18 \mathrm{~S}$ rDNA genomic PCR product, $100 \mathrm{pmol}$ of primers, $20 \mathrm{nmol}$ each of three nucleotides dATP, dGTP, and dTTP, 2 nmol dCTP, $5 \mu$ of $\left[{ }^{32} \mathrm{P}\right] \mathrm{dCTP}$ $(3,000 \mathrm{Ci} / \mathrm{mmol})$ and $2.5 \mathrm{U}$ of Hi-Taq DNA polymerase (Bioprobe). PCR was carried out for 30 cycles as follows: $94^{\circ} \mathrm{C}$ for 30 seconds for denaturing; $60^{\circ} \mathrm{C}$ for 1 minute for annealing; and $72^{\circ} \mathrm{C}$ for 1 minute for extension, followed by one extension cycle at $72^{\circ} \mathrm{C}$ for 5 minutes. Hybridization was carried out in $5 \times$ SSPE, $0.5 \%$ SDS, $5 \times$ Denhardt's at $65^{\circ} \mathrm{C}$ and $20 \mu \mathrm{g} / \mathrm{ml}$ sonicated salmon sperm DNA. Washes were done twice in $2 \times$ SSPE, $0.1 \%$ SDS at room temperature, once for 15 minutes at $65^{\circ} \mathrm{C}$ in $1 \times \mathrm{SSPE}, 0.1 \%$ SDS and once for 10 minutes at $65^{\circ} \mathrm{C}$ in $0.1 \times \mathrm{SSPE}, 0.1 \% \mathrm{SDS}$.

\section{Actin cleavage assay}

Two different protocols were used. In the first experiments, cells were resuspended in PBS- $0.5 \%$ NP40. Protein concentration of cell extracts was determined by the method of Bradford (1976) and $40 \mu \mathrm{g}$ of protein were incubated for 30 minutes in this buffer. In subsequent experiments, cells were resuspended in $10 \mathrm{mM}$ Tris- $\mathrm{HCl}, \mathrm{pH} 8.1$, and $5 \mathrm{mM}$ DTT and freeze-thawed four times as described by Black et al. (1989). A $100 \mu \mathrm{g}$ sample of protein was incubated for 2 hours at $37^{\circ} \mathrm{C}$ in $20 \mathrm{mM}$ Hepes, $\mathrm{pH} 7.5,2 \mathrm{mM}$ DTT and $10 \%$ glycerol with or without $100 \mu \mathrm{M}$ YVAD-CMK (N(N-acetyl-tyrosyl-valinyl-alanyl)) (Bachem). For western blotting, after 15\% SDS-PAGE electrophoresis, proteins were transferred to $0.45 \mu \mathrm{m}$ pore size PVDF membrane (Boehringer Mannheim) using a semi-dry blotting apparatus (transfer buffer: $20 \%$ ethanol, $48 \mathrm{mM}$ Tris, $39 \mathrm{mM}$ glycine and $0.0375 \%$ SDS). After staining with Ponceau $\mathrm{S}$, the membranes were saturated for 1 hour with $5 \%$ non-fat dry milk in TBS (50 mM Tris- $\mathrm{HCl}, \mathrm{pH} 7.6,500$ $\mathrm{mM} \mathrm{NaCl}$ ) and incubated overnight at $4{ }^{\circ} \mathrm{C}$ with the specific anti-actin monoclonal antibody (AC40 or JLA20 from Sigma and Amersham, respectively). Blots were rinsed four times for 7 minutes with TBSTween $(0.1 \%)$ and reacted with peroxidase-conjugated anti-mouse antibody (BioSys) for 1 hour at room temperature. The blots were rinsed for 7 minutes four times with TBS-Tween and revealed with an ECL kit (Amersham). Relative molecular mass was estimated by comparison with the migration of Rainbow ${ }^{\mathrm{TM}}$ colored protein markers (Amersham).

\section{Fluorescence microscopy}

For indirect fluorescence microscopy, cultured cells were grown on glass coverslips under the conditions described and then fixed with $3.7 \%$ paraformaldehyde in PBS for 10 minutes at room temperature, washed twice with PBS and permeabilized with acetone for 3 minutes at $-20^{\circ} \mathrm{C}$. Fixed cells were washed three times with PBS. The coverslips were then treated with the first antibody diluted in PBS-BSA (3\%) for 1 hour at room temperature, washed with PBSTween $(0.1 \%)$ three times and incubated with lissamine rhodamineconjugated anti-mouse secondary antibody (Jackson Immuno Research) for 40 minutes. DAPI (final concentration: $10 \mu \mathrm{g} / \mathrm{ml}$, Sigma) was added to the coverslips 5 minutes before the end of incubation and the coverslips were washed twice with PBS-Tween. Experiments in which the first antibody was omitted were also performed as controls.

Alternatively, for detection of actin filaments, cells were fixed and permeabilized as described above and fluorescein-phalloidin (Molecular probe) was used according to the manufacturer's instructions with 2 units/coverslip. Coverslips were then washed twice with PBS-Tween, incubated for 5 minutes in PBS-BSA plus $1 \mu \mathrm{g} / \mathrm{ml}$ propidium iodide (Sigma) or $10 \mu \mathrm{g} / \mathrm{ml}$ DAPI and washed again twice with PBS-Tween.

Coverslips were mounted in glycerol/PBS solution (Citifluor) and cells were examined by epifluorescence with a Leitz DMRB Leica microscope. 


\section{RESULTS}

\section{The amount of $\gamma$-actin mRNA decreases during apoptosis}

Although in some systems induction of apoptosis by p53 involves transcriptional activation (Yonish et al., 1995; Attardi et al., 1996), in other cases p53-dependent apoptosis seems to occur in the absence of transcriptional activation of p53-target genes (Caelles et al., 1994; Haupt et al., 1995) which suggests that, in some cells, p53 can mediate apoptosis by repressing certain genes. We have used the mRNA differential display method to isolate genes differentially expressed during apoptosis of cell lines conditionally immortalized by SV40. Among the cDNAs identified on the sequencing gel, one was found in marked lower abundance in apoptotic REtsAF cells but not REtsAF-Rev (Fig. 1). It has been reamplified, cloned and sequenced. The sequence of the insert (211 bp), which was in fact generated by amplification between a $\mathrm{T}_{12} \mathrm{AC}$ and a $\mathrm{T}_{12} \mathrm{CC}$ primer (data not shown), was used to search for sequence similarity with the EMBL library. The sequence was found to be identical to the end of the $3^{\prime}$-untranslated region of the rat $\gamma$-actin mRNA (nucleotide 1,640 to 1,851 according to Brown et al., 1990) (data not shown). Thus, this plasmid has been named pCR- $\gamma \mathrm{A}-3^{\prime} \mathrm{UT}$.

\section{The gene encoding $\beta$-actin is also down-regulated}

In order to determine if the decrease in $\gamma$-actin mRNA is specific for this actin isoform or if the other cytoplasmic actin gene displays a similar behavior, we have performed northern blot experiments with $\beta$-actin and $\gamma$-actin specific probes made, respectively, from the pSP64-HF $\beta A-3^{\prime} \mathrm{UT}$ and pCR- $\gamma$ A-3'UT plasmid (Fig. 2). As the mRNAs for $\beta$ - and $\gamma$ -

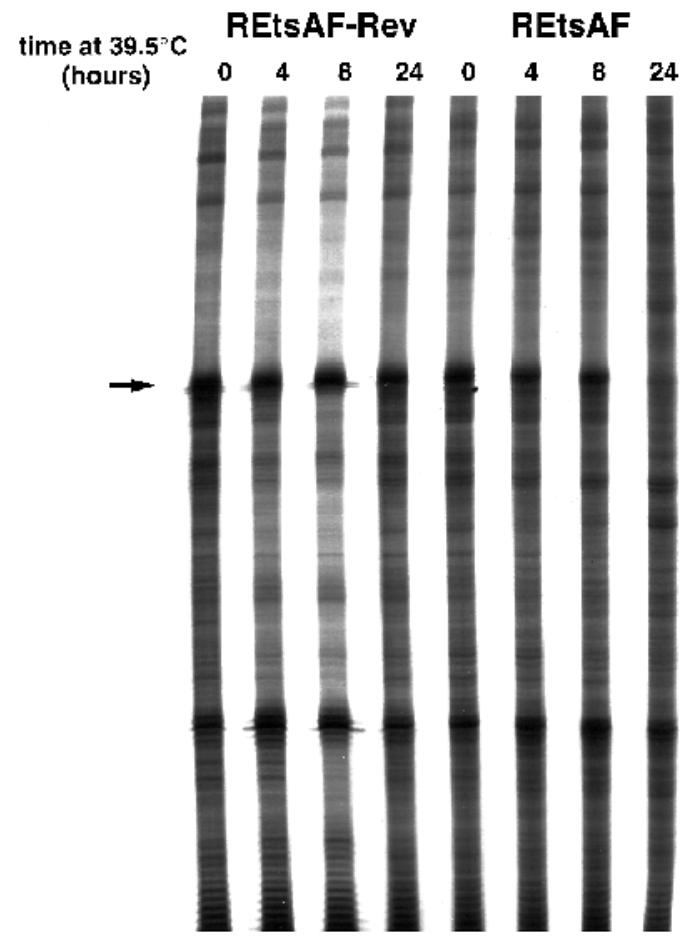

Fig. 1. Differential display of RNA from REtsAF and REtsAF-Rev cell lines at various times after a shift to the restrictive condition. actin are of the same length $(2.1 \mathrm{~kb})$, we used two different blots to measure the change in their respective steady-state levels. The amount of both actin mRNAs decreased during apoptosis of REtsAF cells (Fig. 2A) whereas no difference was observed with control cell lines REtsAF-Rev1 (Fig. 2B) or RELPB (a rat embryo cell line immortalized by wild-type SV40 (Petit et al., 1983; data not shown). Quantification using the Phosphorimager, normalizing to $18 \mathrm{~S}$ rDNA rRNA levels in each sample, showed that, although the level of $\gamma$ actin mRNA reproducibly diminished slightly faster than that of $\beta$-actin, apoptosis of REtsAF is accompanied by a general decrease in levels of mRNA for cytoplasmic actins. After a 24 hour temperature shift, the level of both mRNAs is less than $30 \%$ of that observed before the temperature shift (Fig. 2C). Quantification of actin mRNAs isolated from non temperature sensitive cells (REtsAF-Rev) shows that their levels are not affected by the temperature shift (data not shown).

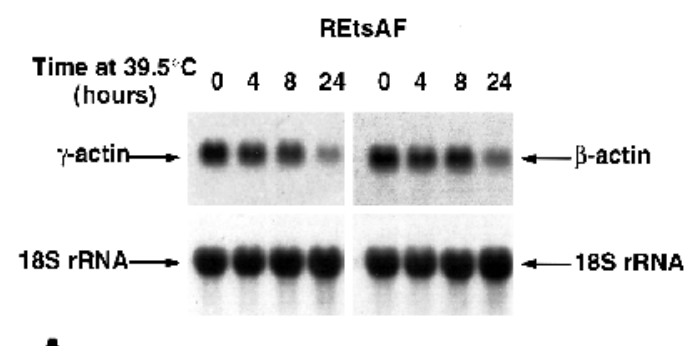

A

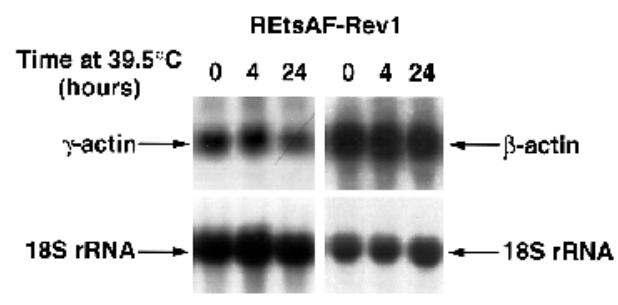

B

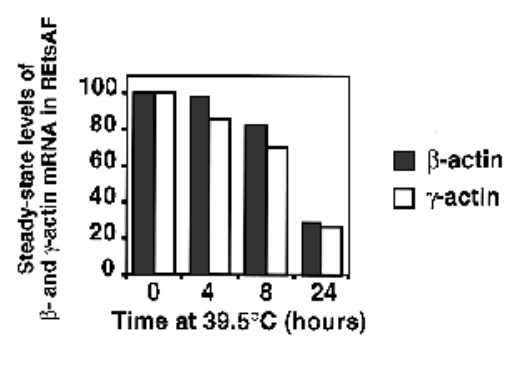

Fig. 2. Steady-state levels of $\beta$-actin and $\gamma$-actin mRNA decrease during REtsAF apoptosis. (A) Total cellular RNA, prepared from $\mathrm{REtsAF}$ at various time after a $39.5^{\circ} \mathrm{C}$ temperature shift, were analyzed by northern blotting. Nylon membrane was probed successively with $\gamma$-actin or $\beta$-actin probe and then with an $18 \mathrm{~S}$ rRNA probe. (B) The same experiment was performed with REtsAFRev1, a cell line that does not undergo apoptosis at $39.5^{\circ} \mathrm{C}$.

(C) Quantification of the steady-state levels of $\beta$ - and $\gamma$-actin mRNA during REtsAF apoptosis at $39.5^{\circ} \mathrm{C}$. Data were standardized according to the relative intensity of the $18 \mathrm{~S}$ rRNA band. Results are expressed as a percentage relative to their matched control. 


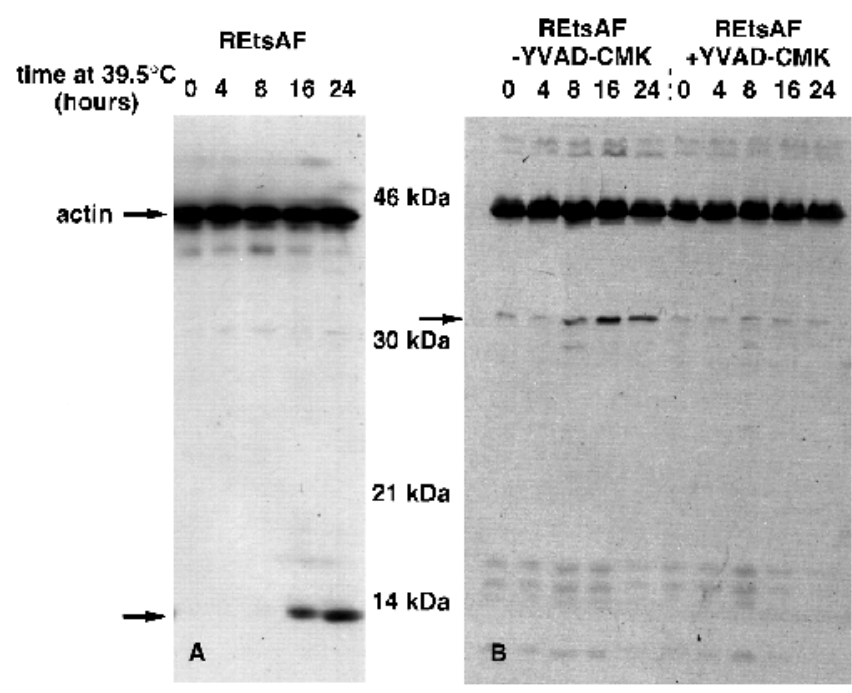

Fig. 3. Actin is a substrate for an ICE-like protease activated during REtsAF apoptosis. (A) extracts of REtsAF cells shifted for various time at $39.5^{\circ} \mathrm{C}$ were incubated for 30 minutes at $37^{\circ} \mathrm{C}$ in lysis buffer as described in Materials and Methods, separated by SDS-PAGE electrophoresis and analyzed by immunoblotting with the AC40 monoclonal antibody. (B) extracts of REtsAF cells shifted for various time at $39.5^{\circ} \mathrm{C}$ were incubated for 2 hours at $37^{\circ} \mathrm{C}$ in ICE buffer with or without $100 \mu \mathrm{M}$ of the YVAD-CMK peptide, separated by SDSPAGE electrophoresis and analyzed by immunoblotting with the JLA20 monoclonal antibody.

\section{Actin is a substrate of an ICE-like protease activated during apoptosis but only a small amount is proteolysed during the early stages of REtsAF apoptosis}

In order to monitor the behavior of actin proteins, we have performed western blotting with two anti-actin antibodies. We found that, although the global amount of actin is approximately constant during apoptosis, an approximately $13 \mathrm{kDa}$ polypeptide that reacts with the AC40 monoclonal antibody is produced in apoptotic cell extracts if the sample is kept for 30 minutes in lysis buffer at $37^{\circ} \mathrm{C}$ before electrophoresis (Fig. $3 \mathrm{~A})$. As the epitope recognized by the antibody is located at the $\mathrm{C}$ terminus of the protein, this $13 \mathrm{kDa}$ polypeptide could be an actin C-terminal fragment produced during apoptosis. We used a second monoclonal antibody (JLA20), that recognizes a different epitope, to check if the complementary $\mathrm{N}$ terminal fragment can be detected. For this experiment, protein extracts were prepared as described in Materials and Methods and incubated with and without $100 \mu \mathrm{M}$ of the YVAD-CMK peptide which is a potent inhibitor of ICE-like proteases. Fig. 3B shows that an actin fragment of about $30 \mathrm{kDa}$ is detected when apoptotic extracts are incubated before electrophoresis. Furthermore, this fragment in not produced when the incubation is performed in the presence of YVAD-CMK, showing that an ICE-like protease is responsible for this proteolysis. Thus, as described in U937 leukemia cells (Mashima et al., 1995), actin is a substrate of an ICE-like protease activated during REtsAF apoptosis; however, only a small amount (if any) of actin is proteolysed until advanced stages of the process.

\section{Immunofluorescence analysis of the reorganization of the microfilament network}

Changes in the microfilament network have been monitored by immunofluorescence analysis during REtsAF apoptosis by using anti-actin antibodies, and fluorescein-phalloidin (which binds specifically to filamentous actin). The results are shown in Figs 4 and 5: after 24 hours, the microfilament network appeared clearly affected. In particular, an accumulation of fluorescein-phalloidin could be seen near the plasma membrane of apoptotic cells, apparently in regions where cells lose adherence to the plastic dishes, and actin fibers appeared thicker. No such changes were seen in similarly treated REtsAF-Rev1 cells (data not shown) Since these changes were not seen after a 6 hour shift, the down-regulation of cytoplasmic actin genes occurs prior to the microfilament rearrangement. Staining with anti-actin antibody showed that actin accumulated in apoptotic bodies during apoptosis (Fig. 5D). In contrast, a very weak signal was observed in apoptotic bodies when fluorescein-phalloidin is used (Fig. 5B). This result shows that, although unpolymerized actin is found in apoptotic bodies, they are devoid of microfilaments. It can also be seen that, in contrast to the result obtained with phalloidin, a low signal is observed in apoptotic cells when using the anti-actin antibody.

\section{DISCUSSION}

Several published observations, some of them apparently contradictory, suggest that microfilament reorganization may be an integral part of the apoptotic process. It has been observed that microfilament-disrupting agents prevent the formation of apoptotic bodies in cells undergoing apoptosis independently of DNA fragmentation (Cotter et al., 1992). However, a microfilament deficiency has been observed during apoptosis which suggests that blebbing of the cytoplasmic membrane during apoptosis is associated with reduced filamentous actin
Fig. 4. Changes in the microfilament network during REtsAF cells apoptosis occur late during the process. REtsAF cells, shifted up to $39.5^{\circ} \mathrm{C}$ for 0,6 or 24 hours, were analyzed by fluorescence microscopy after staining with fluoresceinphalloidin (green fluorescence) and propidium iodide (red fluorescence) as described in Materials and Methods. (A) Cells grown at $33^{\circ} \mathrm{C}$. (B) Cells shifted to $39.5^{\circ} \mathrm{C}$ for 6 hours. (C and D) Cells shifted to $39.5^{\circ} \mathrm{C}$ for 24 hours. Bars, $50 \mu \mathrm{m}$.
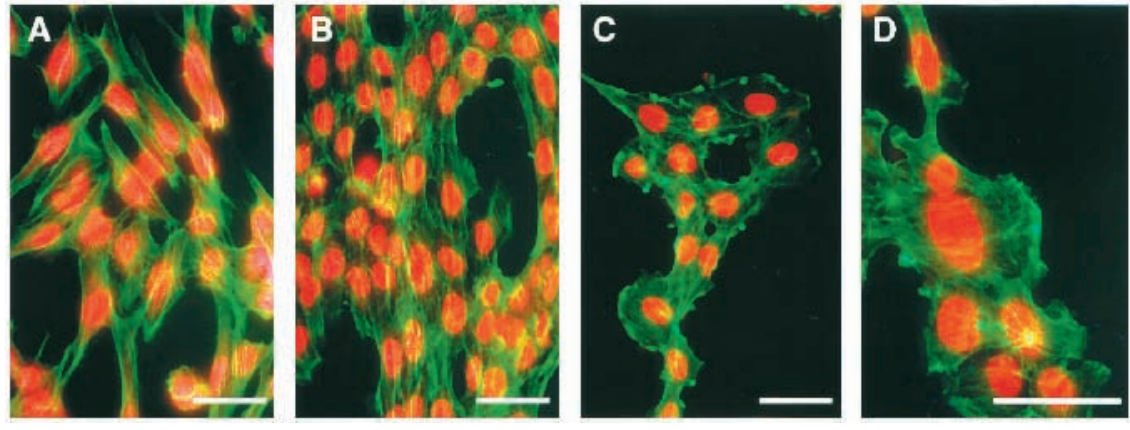

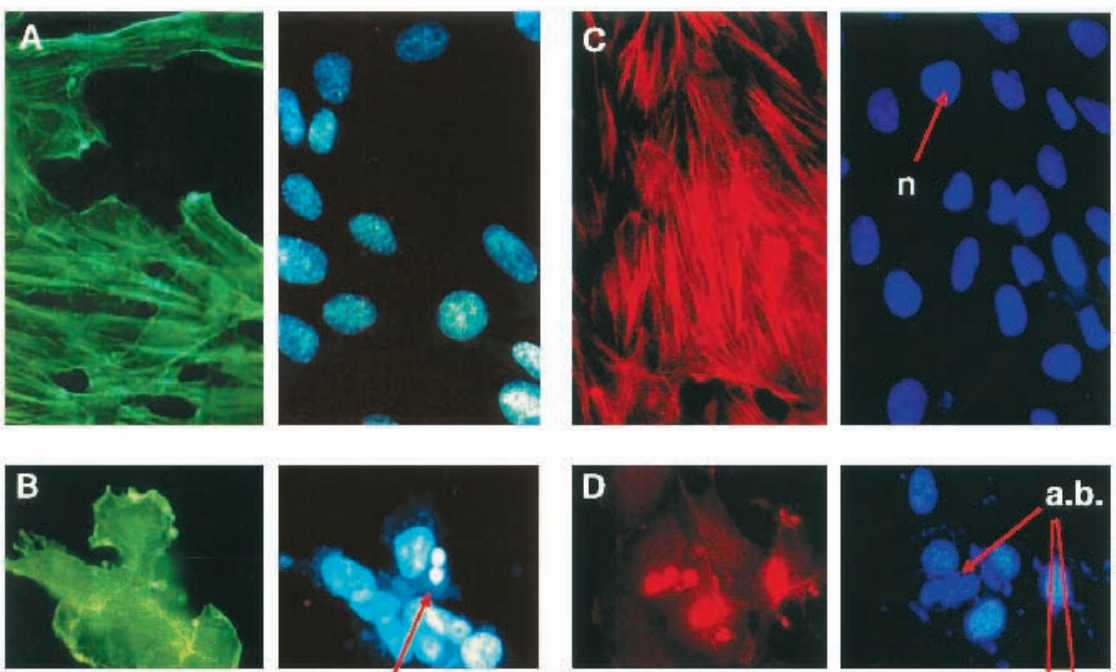

Fig. 5. Status of actin in apoptotic bodies. REtsAF cells kept at $33^{\circ} \mathrm{C}$ (A and C) or shifted for 24 hours to $39.5^{\circ} \mathrm{C}(\mathrm{B}$ and $\mathrm{D})$ were stained with DAPI and either with fluorescein-phalloidin (A and $\mathrm{B}$ ) or with the AC40 anti-actin monoclonal antibody (C and D). n, nucleus; ab, apoptotic body.

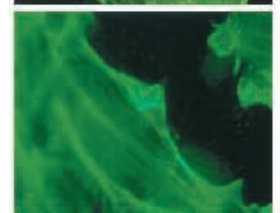

phalloïdin

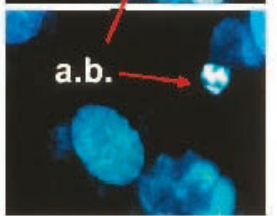

dapi

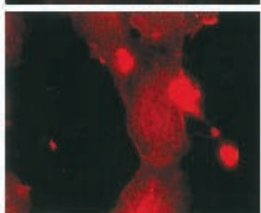

anti-actin

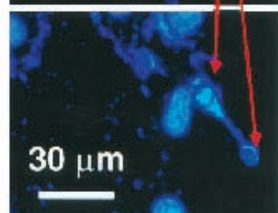

dapi
(Endresen et al., 1995a,b). Expression of thymosine $\beta 10$, a globular actin-binding protein that induces depolymerization of microfilaments, increases the ability of NIH3T3 cells to enter apoptosis induced by TNF $\alpha$ or calcium ionophore (A23187), whereas inhibition of thymosin expression by antisense experiments induces the formation of large actin stress fibers and appears to protect against apoptosis-inducing stimuli (Hall, 1995). It has also been reported that cytochalasin B induces DNA fragmentation similar to that observed during the degradation phase of apoptosis via its effect on the actin filaments (Kolber et al., 1990). However, this effect is not found in all the cell lines tested. One possibility to explain the induction of DNA fragmentation is that the binding of free monomeric actin to DNaseI might inhibit its activity in nonapoptotic cells and that binding of thymosin or cytochalasin to monomeric actin abolishes this effect. In fact, microfilaments could be involved in both the effector phase and the degradation phase. Microfilament depolymerization may be involved in the morphological changes occuring during the effector phase (loss of adherence, cellular shrinkage and blebbing of the plasma membrane) while the polymerization of specific microfilaments or the stabilization of some already polymerized microfilaments could be necessary for the formation of apoptotic bodies occuring latter during the process.

Analysis by fluorescence microscopy of the actin network during apoptosis of REtsAF cells shows that the microfilament network is moderately affected until the late phases of the process. However, analysis of apoptotic cells with anti-actin antibody shows that the microfilament network becomes less accessible to the antibody, which suggests that other components, possibly actin binding proteins, are bound to microfilaments. Alternatively, apoptosis could be associated with changes in actin structure that render it a poor substrate for antibody binding. This experiment also showed that only non- polymerized actin is present in apoptotic bodies. Thus, microfilaments are needed for the formation of apoptotic bodies (Cotter et al., 1992), but the network is rapidly destroyed once the apoptotic bodies get loose from the cell.

How is the disruption of the microfilament network mediated? We observe that actin protein is a putative substrate for an ICE-like protease activated during apoptosis, confirming the study of Mashima et al. (1995) during drug-induced apoptosis of U937 cells. This observation suggests that cleavage of actin might contribute to the cytoskeleton rearrangements seen during apoptosis. However, although we detect this ICE-like activity after 8 to 16 hours in restrictive conditions, cleaved actin is nearly undetectable if the cellular extracts are not pre-incubated before electrophoresis. This is the case even in extracts of cells that have been held for 24 hours in restrictive conditions, i.e. when nearly all the cells were irreversibly committed to death (Vayssière et al., 1994). Furthermore, we do not observe any significant decrease in the steady-state levels of actin proteins, which would have been expected if protein cleavage operated together with gene downregulation. Thus, although this ICE-like protease is activated relatively early during the process, proteolysis of actin occurs late and is therefore probably an event of the degradation phase of apoptosis rather than an event of the effector phase. Alternatively, the ICE-like protease could cleave only a minor subpopulation of actin (for example globular actin) during apoptosis.

In contrast, the decrease in the steady-state levels of $\gamma$ - and $\beta$-actin mRNAs is detected as soon as 4 hours and 8 hours, respectively, after the shift up to $39.5^{\circ} \mathrm{C}$. Following a 24 hour shift (when only $20 \%$ of the cells remain able to grow when shifted back to $33^{\circ} \mathrm{C}$; Vayssière et al., 1994) the levels of $\gamma$ and $\beta$-actin mRNAs are less than $30 \%$ of those observed before the temperature shift, whereas the steady-state levels of most 
mRNAs are stable (Guénal and Mignotte, 1995). Thus, this decrease in actin mRNA levels could be related to the morphological changes occuring during apoptosis.

It is well known that regulation of gene expression is one of the levels of control of microfilament network structure. Every mammalian cell contains several actin isoforms encoded by a gene family (Vandekerckhove et al., 1981; Chang et al., 1984). These genes belong to three classes, depending on the isoelectric point of the protein. $\beta$-Actin and $\gamma$-actin are the main components of microfilaments in non-muscle cells. Although they are generally coexpressed, they exhibit specific regulation (Vandekerckhove et al., 1981). The expression of actin genes is controlled by various external signals, including EGF (Elder et al., 1984), TGF- $\beta$ (Leof et al., 1986), insulin (Weinstock et al., 1993); cytosolic calcium appears to be involved in at least some of these up-regulations (Weinstock et al., 1993). A feedback regulation has also been detected by experiments where the microfilaments were stabilized by phalloidin. In that situation, the concentration in monomeric actin decreases and actin mRNA levels increase (Serpinskaya et al., 1990). However, $\beta$-actin is not simply autoregulated since overexpression of an exogenous $\beta$-actin induces the expression of the endogenous gene (Lloyd et al., 1992). In contrast, exogenous $\gamma$-actin appears to repress both $\beta$ - and $\gamma$-actin gene expression and this effect can be abolished by cytochalasin B. Untranslated regions also appear to be involved in controling the microfilament network structure. For example, a 3' untranslated region of the $\beta$-actin gene is responsible for its localization to the periphery of the cell and thus affects the cellular morphology (Kislauskis et al., 1994); transfectants expressing the $\gamma$-actin gene deleted for intron III are rounded with blebs over the cell surface and show decreased surface area (Lloyd and Gunning, 1993), morphological changes that are reminiscent of apoptosis. Thus, changes in actin mRNA steady-state levels during apoptosis could regulate the microfilament network not only by controlling the quantity of actin in the cell but also by a qualitative effect on spatial distribution of actin message within the cell.

We have found that a decrease in the mRNA for $\gamma$-actin precedes that of $\beta$-actin by a few hours. To our knowledge, no data concerning the regulation of $\gamma$-actin expression during apoptosis are yet available. A specific decrease in steady-state levels of $\beta$-actin mRNA have been recently reported to be associated with apoptosis of HL-60 and U-937 cells induced by actinomycin D (Naora and Naora, 1995). However, in response to apoptosis induced by cycloheximide or calcium ionophore (A23187) those authors observe an increase in $\beta$-actin mRNA levels, so they suggest that a decrease in $\beta$-actin expression may not be related to apoptosis. However, cycloheximide or A23187 are known inducers of actin gene expression (Elder et al., 1984; Weinstock et al., 1993) and apoptosis induced by these agents may not be representative of the general picture. Thus, the repression of actin genes observed during REtsAF apoptosis at $39.5^{\circ} \mathrm{C}$ could be a widespread phenomena involved in microfilament rearrangements during apoptosis.

We thank Drs J. L. Vayssière and C. Sidoti for helpful discussions; F. Coquelle who participated in some of the experiments described in this paper; and Drs R. Karess, M. Laurent and F. Mignotte for their critical reading of the manuscript. We acknowledge G. Stepien for providing us with the $18 \mathrm{~S}$ rDNA PCR product and oligonucleotides and Dr Gabiani for the gift of plasmid pSP64-HFßA-3'UT. This work was supported in part by grants from the Association pour la Recherche contre le Cancer (\#6960), from the Ligue Nationale Contre le Cancer and from the Ministère de l'Education Nationale de l'Enseignement Supérieur et de la Recherche (ACC-SV4). I.G. was supported by a fellowship from the Ligue Nationale Contre le Cancer.

\section{REFERENCES}

Attardi, L. D., Lowe, S. W., Brugarolas, J. and Jacks, T. (1996). Transcriptional activation by p53, but not induction of the p21 gene, is essential for oncogene mediate apoptosis. EMBO J. 15, 3693-3701.

Black, R. A., Kronheim, S. R. and Sleath, P. R. (1989). Activation of interleukin-1 beta by a co-induced protease. FEBS Lett. 247, 386-390.

Bradford, M. M. (1976). A rapid and sensitive method for the quantitation of a microgram of protein utilizing the principle of protein-dye binding. Anal. Biochem. 72, 248-254.

Brancolini, C., Benedetti, M. and Schneider, C. (1995). Microfilament reorganization during apoptosis: the role of Gas2, a possible substrate for ICE-like proteases. EMBO J. 14, 5179-5190.

Brown, C. W., McHugh, K. M. and Lessard, J. L. (1990). A cDNA sequence encoding cytoskeletal gamma-actin from rat. Nucl. Acids Res. 18, 5312.

Caelles, C., Helmberg, A. and Karin, M. (1994). p53-dependent apoptosis in the absence of transcriptional activation of p53-target genes. Nature 370, 220-223.

Chang, K. S., Zimmer, W. J., Bergsma, D. J., Dodgson, J. B. and Schwartz, R. J. (1984). Isolation and characterization of six different chicken actin genes. Mol. Cell. Biol. 4, 2498-2508.

Chirgwin, J. M., Przybyla, A. E., MacDonald, R. J. and Rutter, W. J. (1979). Isolation of biologically active ribonucleic acid from sources enriched in ribonuclease. Biochemistry 18, 5294-5299.

Clarke, P. G. H. (1990). Developmental cell death: morphological diversity and multiple mechanisms. Anat. Embryol. 181, 195-213.

Cotter, T. G., Lennon, S. V., Glynn, J. M. and Green, D. R. (1992). Microfilament-disrupting agents prevent the formation of apoptotic bodies in tumor cells undergoing apoptosis. Cancer Res. 52, 997-1005.

Elder, P. K., Schmidt, L. J., Ono, T. and Getz, M. J. (1984). Specific stimulation of actin gene transcription by epidermal growth factor and cycloheximide. Proc. Nat. Acad. Sci. USA 81, 7476-7480.

Ellis, R. E., Yuan, J. Y. and Horvitz, H. R. (1991). Mechanisms and functions of cell death. Annu. Rev. Cell Biol. 7, 663-698.

Endresen, P. C., Fandrem, J., Eide, T. J. and Aarbakke, J. (1995a). Morphological modifications of apoptosis in HL-60 cells: effects of homocysteine and cytochalasins on apoptosis initiated by 3-deazaadenosine. Vircows Achiv. 426, 257-266.

Endresen, P. C., Prytz, P. S. and Aarbakke, J. (1995b). A new flow cytometric method for discrimination of apoptotic cells and deletion of their cell cycle specificity through staining of F-actin and DNA. Cytometry 20, 162-171.

Guénal, I. and Mignotte, B. (1995). Studies of specific gene induction during apoptosis of cell lines conditionally immortalized by SV40. FEBS Lett. 374, 384-386.

Hall, A. K. (1995). Thymosin beta-10 accelerates apoptosis. Cell. Mol. Biol. Res. 41, 167-180.

Haupt, Y., Rowan, S., Shaulian, E., Vousden, K. H. and Oren, M. (1995). Induction of apoptosis in HeLa cells by trans-activation-deficient p53. Genes Dev. 9, 2170-2183.

Kayalar, C., Örd, T., Testa, M. P., Zhong, L. T. and Bredesen, D. E. (1996). Cleavage of actin by interleukin $1 \beta$-converting enzyme to reverse DNase I inhibition. Proc. Nat. Acad. Sci. USA 93, 2234-2238.

Kerr, J. F. R., Wyllie, A. H. and Currie, A. R. (1972). Apoptosis: a basic biological phenomenon with wide-ranging implications in tissue kinetics. $\mathrm{Br}$. J. Cancer 26, 239-257.

Kislauskis, E. H., Zhu, X. and Singer, R. H. (1994). Sequences responsible for intracellular localization of beta-actin messenger RNA also affect cell phenotype. J. Cell Biol. 127, 441-451.

Kocher, O. and Gabbiani, G. (1986). Expression of actin mRNAs in rat aortic smooth muscle cells during development, experimental intimal thickening, and culture. Differentiation 32, 245-251.

Kolber, M. A., Broschat, K. O. and Landa, G. B. (1990). Cytochalasin B induces cellular DNA fragmentation. FASEB J. 4, 3021-3027. 
Kroemer, G., Petit, P. X., Zamzami, N., Vayssière, J. L. and Mignotte, B. (1995). The biochemistry of programmed cell death. FASEB J. 9, 1277-1287. Kumar, S. (1995). ICE-like proteases in apoptosis. Trends Biochem. Sci. 20 198-202.

Leof, E. B., Proper, J. A., Getz, M. J. and Moses, H. L. (1986). Transforming growth factor type beta regulation of actin mRNA. J. Cell. Physiol. 127, 8388.

Liang, P. and Pardee, A. (1992). Differential display of eucaryotic messenger RNA by means of the polymerase chain reaction. Science 257, 967-971.

Liang, P., Bauer, D., Averboukh, L., Warthoe, P., Rohrwild, M., Muller, H., Strauss, M. and Pardee, A. B. (1995). Analysis of altered gene expression by differential display. Meth. Enzymol. 254, 304-321.

Lloyd, C., Schevzov, G. and Gunning, P. (1992). Transfection of nonmuscle beta- and gamma-actin genes into myoblasts elicits different feedback regulatory responses from endogenous actin genes. J. Cell Biol. 117, 787797.

Lloyd, C. and Gunning, P. (1993). Noncoding regions of the gamma-actin gene influence the impact of the gene on myoblast morphology. J. Cell Biol. 121, 73-82.

Martin, S. J. and Green, D. R. (1995). Protease activation during apoptosis: death by a thousand cuts? Cell 82, 349-352.

Martin, S. J., O'Brien, G. A., Nishioka, W. K., McGahon, A. J., Mahboubi, A., Saido, T. C. and Green, D. R. (1995). Proteolysis of fodrin (nonerythroid spectrin) during apoptosis. J. Biol. Chem. 270, 6425-6428.

Mashima, T., Naito, M., Fujita, N., Noguchi, K. and Tsuruo, T. (1995). Identification of actin as a substrate of ICE and an ICE-like protease and involvement of an ICE-like protease but not ICE in VP-16-induced U937 apoptosis. Biochem. Biophys. Res. Commun. 217, 1185-1192.

Mignotte, B., Larcher, J. C., Zheng, D. Q., Esnault, C., Coulaud, D. and Feunteun, J. (1990). SV40 induced cellular immortalization: phenotypic changes associated with the loss of proliferative capacity in a conditionally immortalized cell line. Oncogene 5, 1529-1533.

Naora, H. and Naora, H. (1995). Differential expression patterns of beta-actin mRNA in cells undergoing apoptosis. Biochem. Biophys. Res. Commun. 211 491-496.

Nicoletti, I., Migliorati, G., Pagliacci, M. C., Grignani, F. and Riccardi, C. (1991). A rapid and simple method for measuring thymocyte apoptosis by propidium iodide staining and flow cytometry. J. Immunol. Meth. 139, 271279.

Petit, C. A., Gardes, M. Y. and Feunteun, J. (1983). Immortalization of rodent embryo fibroblast by SV40 is maintained by the A gene. Virology 127, 74-82.

Reed, K. and Mann, D. (1985). Rapid transfer of DNA from agarose gel to nylon membrane. Nucl. Acids Res. 13, 7207-7221.

Schwartz, L. M., Smith, S. W., Jones, M. E. E. and Osborne, B. A. (1993) Do all programmed cell deaths occur via apoptosis? Proc. Nat. Acad. Sci. USA 90, 980-984.

Serpinskaya, A. S., Denisenko, O. N., Gelfand, V. I. and Bershadsky, A. D. (1990). Stimulation of actin synthesis in phalloidin-treated cells. Evidence for autoregulatory control. FEBS Lett. 277, 11-14.

Shi, Y., Glynn, J. M., Guilbert, L. J., Cotter, T. G., Bissonnette, R. D. and Green, D. R. (1992). Role for c-myc in activation-induced apoptotic cell death in T cell hybridomas. Science 257, 212-214.

Swat, W., Ignatowicz, L. and Kisielow, P. (1991). Detection of apoptosis of immature thymocytes by flow cytometry. J. Immunol. Meth. 137, 79-87.

Thompson, C. B. (1995). Apoptosis in the pathogenesis and treatment of disease. Science 267, 1456-1462.

Vandekerckhove, J., Franke, W. W. and Weber, K. (1981). Diversity of expression of non-muscle actin in amphibia. J. Mol. Biol. 152, 413-426.

Vayssière, J. L., Petit, P. X., Risler, Y. and Mignotte, B. (1994). Commitment to apoptosis is associated with changes in mitochondrial biogenesis and activity in cell lines conditionally immortalized with Simian Virus 40. Proc. Nat. Acad. Sci. USA 91, 11752-11756.

Weinstock, R. S., Saville, C. M. and Messina, J. L. (1993). Role of cytosolic calcium in regulation of cytoskeletal gene expression by insulin. Am. $J$. Physiol. E519-25.

Yanai, N. and Obinata, M. (1994). Apoptosis is induced at nonpermissive temperature by a transient increase in p53 in cell lines immortalized with temperature-sensitive SV40 large T-antigen gene. Exp. Cell Res. 211, 296300.

Yonish, R. E., Deguin, V., Zaitchouk, T., Breugnot, C., Mishal, Z., Jenkins, J. R. and May, E. (1995). Transcriptional activation plays a role in the induction of apoptosis by transiently transfected wild-type p53. Oncogene 11, 2197-2205.

Zheng, D. Q., Vayssière, J. L., Lecoeur, H., Petit, P. X., Spatz, A., Mignotte, B. and Feunteun, J. (1994). Apoptosis is antagonized by large T antigens in the pathway to immortalization by polyomaviruses. Oncogene 9, 3345-3351.

(Received 9 August 1996 - Accepted 5 December 1996) 